\title{
PERLIDUNGAN HUKUM BAGI KONSUMEN OBAT KUAT ILEGAL DITINJAU DARI UNDANG-UNDANG NOMOR 8 TAHUN 1999*
}

\author{
Oleh: \\ Komang Adi Murti Pranata ${ }^{* *}$ \\ Dewa Gde Rudy ${ }^{* * *}$ \\ Fakultas Hukum Universitas Udayana \\ Pogram Kekhususan Hukum Bisnis
}

\begin{abstract}
ABSTRAK
Dalam perkembangan dunia bisnis, sering terjadi kasus yang dapat merugikan konsumen. Salah satunya adalah peredaran obat kuat ilegal. Hal ini jelas merugikan konsumen di Indonesia karena obat kuat yang diedarkan tidak memiliki izin dari Badan Pengawas Obat dan Makanan sehingga belum dapat menjamin keselamatan dan kenyamanan bagi penggunaannya. Selain itu, obat kuat tersebut mengandung bahan kimia obat (BKO) yang berbahaya untuk kesehatan bahkan dapat mengakibatkan kematian. Permasalahan yang diangkat di dalam permasalahan ini adalah mengenai perlindungan hukum terhadap konsumen terkait peredaran obat kuat ilegal dan tanggung jawab pelaku usaha apabila konsumen mengalami kerugian akibat mengkonsumsi obat kuat ilegal.

Metode penelitian yang digunakan dalam penulisan ini adalah penelitian hukum normatif. Tujuan penelitian ini adalah untuk mengetahui perlindungan hukum bagi konsumen obat kuat ilegal dan tanggung jawab pelaku usaha terhadap konsumen yang dirugikan akibat mengkonsumsi obat kuat ilegal. Tulisan ini menghasilkan penelitian bahwa perlindungan hukum terhadap konsumen yang dirugikan wajib mendapatkan hak-haknya seperti hak atas kenyamanan, keamanan, dan keselamatan dalam mengkonsumusi obat kuat ilegal. Selain itu, peredaran obat kuat ilegal ini mendapatkan pengawasan dari Badan Pengawas Obat dan

*Tulisan ini merupakan tulisan ilmiah diluar ringkasan skripsi.

** Komang Adi Murti Pranata, adalah Mahasiswa Fakultas Hukum Universitas Udayana, odonmurti@yahoo.com.

${ }^{* * *}$ Dewa Gde Rudy, adalah Dosen Pengajar Bidang Hukum Bisnis Fakultas Hukum Universitas Udayana.
\end{abstract}


Makanan . Pelaku usaha bertanggung jawab memberikan ganti rugi berupa pengembalian uang atau penggantian barang dan/atau jasa yang sejenis atau setara nilainya, atau perawatan kesehatan dan/atau pemberian santunan yang sesuai dengan ketentuan peraturan perundang-undangan yang berlaku.

\title{
Kata kunci : Perlindungan Konsumen, Tanggung Jawab, Pelaku Usaha, Obat-Obatan
}

\begin{abstract}
The development of business world, follows with many cases that may harm the consumers. One of the cases is the deployment of illegal strong medicines. This situation harm the consumers in Indonesia because that medication has not had license from Indonesian Department of Drugs and Food. Consequently, the safety and the comfort of that medication cannot be guaranteed. Moreover, that medication contains strong chemical medications that are dangerous for health and can lead to death. The issues that are discussed in this essay are the legal protection for consumers that involve in the deployment of illegal strong medications and the responsibility of the seller if the consumers experience harm because of the medication. The aim of this research is to analyse the legal protection toward consumers and the responsibilities of the seller as a subject that spread the medications.
\end{abstract}

The methods of this research is legal normative research. The purpose of this research is to analyse the legal protection toward consumers and the responsibilities of the seller as a subject that spread the medications. The finding shows that, the consumers as a victim required to get their right to be comfortable, secure and safe in consuming the medication. Besides, the deployment of this medication has to be under supervision from Department of Drugs and Food. The violation toward Department of Drugs and Food policies subject to administrative sanction in the form of writing, the suspension of the activities and revocation of deployment license. The seller responsible to provide compensation in the form of refunds or substitute the medications to other products that have similar values. Furthermore, the businessmen mandate to cover the health care expenses for the victims according to the existences regulation. 


\section{Keywords: consumer protection, responsibilities, the seller, medications}

\section{PENDAHULUAN}

\subsection{Latar Belakang}

Perkembangan perekonomian yang pesat dan kemajuan teknologi dan ilmu pengetahuan telah menimbulkan perubahan yang cukup cepat pada kebutuhan hidup manusia, salah satunya adalah obat-obatan. Obat merupakan salah satu unsur penting dalam pelayanan kesehatan. Diawali dari pencegahan, diagnosa, pengobatan dan pemulihan. Obat sebagai sebuah produk kesehatan yang bermanfaat bagi pasien yang membutuhkannya maka sudah seharusnya pasien sebagai konsumen berhak mengetahui informasi yang jelas terkait obat-obatan yang dikonsumsi, kandungan zat yang ada pada suatu obat, khasiat suatu obat, dan keaslian dari suatu obat tersebut.

Produk obat kuat merupakan obat yang dapat meningkatkan stamina pria pada saat berhubungan seksual. Obat kuat merupakan hasil dari perkembangan industri obat-obatan yang menjadi salah satu kebutuhan pokok masyarakat seiring dengan perkembangan gaya hidup masyarakat. Besarnya minat masyarakat terutama kaum pria untuk mengkonsumsi obat kuat, membuat pelaku usaha untuk memproduksi berbagai macam produk obat kuat tanpa memperhatikan hak-hak konsumen, misalnya produk obat yang ditawarkan kepada konsumen tidak memiliki izin dari Badan Pengawas Obat dan Makanan (yang selanjutnya disebut BPOM) sehingga belum dapat menjamin keselamatan dan kenyamanan pihak konsumen dalam mengonsumsi produk obat kuat tersebut. 
BPOM merupakan Lembaga Pemerintah Non Departemen dalam Pemerintahan Negara Republik Indonesia adalah lembaga pemerintah pusat yang dibentuk untuk melaksanakan tugas pemerintah tertentu dari presiden, berada di bawah presiden dan bertanggung jawab kepada presiden. Di dalam melaksanakan tugas pemerintah tertentu dari presiden, BPOM mempunyai tugas melaksanakan di bidang pengawasan obat dan makanan sesuai dengan ketentuan peraturan perundang-undangan yang berlaku. ${ }^{1}$

Maraknya peredaran produk obat kuat ilegal belakangan ini menimbulkan keresahan bagi masyarakat selaku konsumen. Salah satu contoh kasus adalah adanya peredaran ratusan ribu butir kapsul jamu obat kuat illegal di gagalkan masuk ke Bali. Jamu dengan merk Cobra'X ini tidak dilengkapi daftar BPOM yang sah. Ratusan ribu butir jamu kuat yang dikemas dalam 16 dus besar ini dikirim menggunakan jasa kendaraan ekspedisi. Jamu obat kuat Cobra'X ini, merupakan salah satu jamu yang sudah ditarik peredarannya oleh BPOM karena mengandung bahan kimia obat (BKO) "Sildenafil Sitrat" yang berbahaya untuk kesehatan bahkan dapat mengakibatkan kematian. ${ }^{2}$

Perbuatan yang dilakukan pelaku usaha dalam melakukan peredaran produk obat kuat ilegal tersebut dapat mengancam keselamatan dan kesehatan konsumen sehingga menyebabkan kerugian bagi kehidupan masyarakat. Selain itu, dengan adanya fakta bahwa sebenarnya jamu obat kuat dengan merek Cobra'X

1Zulham, 2018, Peran Negara Dalam Perlindungan Konsumen Muslim Terhadap Produk Obat Halal, Kencana, Jakarta, h. 345.

${ }^{2}$ Nurul Hikmah, 2018, "Polisi Sita Ratusan Ribu Obat Kuat di Pintu Masuk Bali", Oke News, URL: https://news.okezone.com/read/2018/04/11/340/1885311/polisi-sita-ratusanribu-obat-kuat-di-pintu-masuk-bali diakses tanggal 4 April 2019 
sudah tidak mendapatkan izin edar oleh BPOM namun tetap saja produk obat kuat ini beredar bebas sehingga menimbulkan pertanyaan mengenai bagaimana pengawasan BPOM dan tanggung

jawab pemerintah di dalam masalah ini. ${ }^{3}$ Di dalam usaha untuk melindungi kepentingan hak-hak konsumen dari tindakan sewenangwenang pelaku usaha, maka sekarang ini telah ada Undang-Undang yang mengatur yaitu Undang-Undang Nomor 8 Tahun 1999 tentang Perlindungan Konsumen.

Dari pernyataan di atas, penulis akan memaparkan berbagai permasalahan yang akan di bahas di dalam rumusan masalah

\subsection{Rumusan Masalah}

1. Bagaimana perlindungan hukum terhadap konsumen terkait peredaran obat kuat ilegal ?

2. Bagaimana tanggung jawab pelaku usaha apabila konsumen mengalami kerugian akibat mengkonsumsi obat kuat ilegal ?

\subsection{Tujuan Penulisan}

Kajian ini bertujuan untuk memahami dan mengetahui bentuk perlindungan hukum terhadap konsumen terkait peredaran obat kuat ilegal dan tanggung jawab pelaku usaha apabila konsumen mengalami kerugian akibat mengkonsumsi obat kuat ilegal.

\section{ISI MAKALAH}

\subsection{Metode Penelitian}

${ }^{3}$ Humas dan DSP, 2018, "Siaran Pers BPOM RI Sita 15,7 Miliar Rupiah Obat Tradisional Ilegal di Jakarta", Badan Pom, URL:

https://www.pom.go.id/mobile/index.php/view/pers/429/SIARAN-PERS--BPOMRI-SITA-15-7-MILIAR-RUPIAH-OBAT-TRADISIONAL-ILEGAL-DI-JAKARTA.html diakses tanggal 17 Juni 2019 


\subsubsection{Jenis Penelitian}

Jenis penelitian dalam penulisan jurnal ini adalah penelitian normatif. Penelitian hukum normatif mengkaji bahan-bahan yang berisi aturan-aturan yang bersifat normatif. ${ }^{4}$ Jenis pendekatan yang digunakan dalam penulisan jurnal ini adalah pendekatan perundangundangan yang dikaitkan dengan permasalahan yang ada pada kasus.

\subsection{Hasil Analisa}

\subsubsection{Perlindungan hukum terhadap konsumen terkait peredaran obat kuat ilegal}

Perlindungan Hukum adalah memberikan pengayoman kepada hak asasi manusia yang dirugikan orang lain dan perlindungan tersebut diberikan kepada masyarakat agar mereka dapat menikmati semua hak-hak yang diberikan oleh hukum. ${ }^{5}$ Berkaitan dengan konsumen, berarti hukum memberikan perlindungan terhadap hakhak pelanggan dari sesuatu yang mengakibatkan tidak terpenuhinya hak-hak tersebut

Berdasarkan Pasal 1 angka 2 UU No. 8 Tahun 1999 tentang Perlindungan Konsumen menyebutkan bahwa konsumen merupakan setiap orang pemakai barang dan jasa yang tersedia dalam masyarakat, baik bagi kepentingan diri sendiri, keluarga, orang lain, maupun makhluk hidup lain dan tidak untuk diperdagangkan. Dan pelaku usaha merupakan orang atau lembaga yang berbentuk badan hukum maupun yang bukan badan hukum yang didirikan dan berkedudukan atau melakukan kegiatan dalam wilayah hukum

${ }^{4}$ Bahder Johan Nasution, 2008, Metode Penelitian Ilmu Hukum, Mandar Maju, Bandung, h. 86.

${ }^{5} \mathrm{M}$ Soerjono Soekanto, 2006, Pengantar Penelitian Hukum, UI-Press, Jakarta, h. 133. 
Republik Indonesia, baik sendiri maupun bersama-sama melalui perjanjian menyelenggarakan kegiatan usaha dalam berbagai bidang. Hal ini diatur di dalam Pasal 1 angka 3 Undang-Undang Perlindungan Konsumen.

Berdasarkan Pasal 3 Undang-Undang Perlindungan Konsumen, salah satu tujuan dari perlindungan konsumen adalah meningkatkan kualitas barang dan/atau jasa yang menjamin kelangsungan usaha produksi barang dan/atau jasa, kesehatan, kenyamanan, keamanan, dan keselamatan konsumen. Dalam Pasal 4 Undang-Undang Nomor 8 Tahun 1999 tentang Perlindungan Konsumen, salah satu hak konsumen yang pokok untuk membahas mengenai kasus diatas adalah hak atas kenyamanan, keamanan, dan keselamatan dalam mengkonsumsi barang dan/atau. Hal ini karena obat kuat merek Cobra'X yang diedarkan tidak memenuhi standar kesehatan, kualitas produk obat kuat tidak layak untuk dijual karena mengandung bahan kimia obat (BKO) "Sildenafil Sitrat" dan produk obat kuat tersebut ilegal karena tidak memiliki ijin dari BPOM sehingga dapat mengancam kesehatan dan keselamatan konsumen bagi yang mengkonsumsi.

Perlindungan hukum yang dapat diberikan pada pembeli obat kuat merek Cobra'X ada dua yaitu perlindungan hukum preventif dan perlindungan hukum represif. Perlindungan hukum preventif terdapat di dalam Pasal 7, Pasal 8 sampai dengan Pasal 17 UndangUndang Nomor 8 Tahun 1999 tentang perlindungan konsumen. Bunyi Pasal 7 Undang-Undang Perlindungan konsumen yang sesuai dengan kasus obat kuat merek Cobra'X menyebutkan bahwa dalam suatu kegiatan usaha, pelaku usaha memiliki kewajiban untuk menjamin mutu barang dan/atau jasa yang diproduksi dan atau 
diperdagangkan berdasarkan ketentuan standar mutu barang dan/atau jasa yang berlaku serta memberi kompensasi, ganti rugi dan/atau penggantian atas kerugian akibat penggunaan, pemakaian dan pemanfaatan barang dan/atau jasa yang diperdagangkan

Berdasarkan Pasal 8 Undang-Undang Perlindungan Konsumen menyebutkan bahwa pelaku usaha dilarang memproduksi dan/atau memperdagangkan barang dan/atau jasa yang tidak memenuhi atau tidak sesuai dengan standar yang dipersyaratkan dan ketentuan peraturan perundang-undangan, pelaku usaha dilarang memperdagangkan barang yang rusak, cacat atau bekas, dan tercemar tanpa memberikan informasi secara lengkap dan benar atas barang dimaksud serta pelaku usaha dilarang memperdagangkan sediaan farmasi dan pangan yang rusak, cacat atau bekas dan tercemar, dengan atau tanpa memberikan informasi secara lengkap dan benar. Dalam Pasal 17 Undang-Undang Perlindungan Konsumen menyebutkan bahwa pelaku usaha periklanan dilarang memproduksi iklan yang tidak memuat informasi mengenai risiko pemakaian barang dan/atau jasa. Selain itu, perlindungan hukum terhadap peredaran obat kuat ilegal ini juga mendapat pengawasan dari lembaga-lembaga yang berwenang seperti Badan Pengawas Obat dan Makanan.

Adapun perlindungan hukum represif yang dapat diterapkan terkait dengan peredaran obat kuat ilegal merek Cobra'X ada dua yaitu dengan jalur litigasi maupun non litigasi. Penyelesaian sengketa melalui litigasi mengacu pada ketentuan Pasal 45 Undang-Undang Perlindungan Konsumen yang menyebutkan bahwa setiap konsumen yang dirugikan dapat menggugat pelaku usaha melalui lembaga yang bertugas menyelesaikan sengketa antara konsumen dan pelaku 
usaha atau melalui peradilan yang berada di lingkungan peradilan umum. Sedangkan Penyelesaian sengketa non litigasi dapat melalui Badan Penyelesaian Sengketa Konsumen (Selanjutnya disebut BPSK).

Dalam Pasal 52 Undang-Undang Perlindungan Konsumen menyebutkan bahwa BPSK memiliki tugas dan wewenang yaitu menerima pengaduan baik tertulis maupun tidak tertulis, dari konsumen tentang terjadinya pelanggaran terhadap perlindungan konsumen serta menjatuhkan sanksi administratif kepada pelaku usaha yang melanggar ketentuan Undang-Undang. Sanksi administratif terhadap pelaku usaha yang melanggar berupa penetapan ganti rugi paling banyak Rp 200.000.000 (dua ratus juta rupiah). Hal ini diatur di dalam pasal 60 Undang-undang Perlindungan Konsumen. Selain itu, pelanggaran terhadap ketentuan BPOM dapat juga dikenai sanksi administratif berupa peringatan tertulis, penghentian sementara kegiatan serta pembatalan izin edar. Sanksi ini diatur di dalam Peraturan Badan Pengawas Obat dan Makanan Nomor NOMOR HK.00.05.42.2996 Tentang Pengawasan Pemasukan Obat Tradisional.

\subsubsection{Tanggung Jawab Pelaku Usaha Apabila Konsumen Mengalami Kerugian Akibat Mengkonsumsi Obat Kuat Ilegal}

Di dalam konteks perdata, pertanggungjawaban perdata merupakan tindakan, biasanya dalam bentuk pembayaran ganti kerugian, yang harus dilakukan oleh seseorang atau pihak yang karena perbuatannya telah menimbulkan kerugian pada orang lain. Pertanggungjawaban dalam peredaran obat kuat ilegal maka pelaku usaha tetap dapat dituntut pertanggungjawabannya melalui pertanggungjawaban produk (product liability) apabila ternyata 
produk yang ditawarkan oleh pelaku usaha cacat dan merugikan konsumen.

Prinsip tanggung jawab mutlak (strict liability) paling sesuai digunakan dalam kasus peredaran obat kuat ilegal. Prinsip tanggung jawab mutlak adalah prinsip tanggung jawab yang menetapkan kesalahan tidak sebagai faktor yang menentukan. ${ }^{6}$ Prinsip ini dalam hukum perlindungan konsumen secara umum digunakan untuk menjerat pelaku usaha, khususnya produsen yang memproduksi barang sehingga menimbulkan kerugian terhadap konsumen. Asas tanggung jawab tersebut dikenal dengan nama Product Liability. Menurut asas ini, produsen wajib bertanggung jawab atas kerugian yang diderita konsumen atas penggunaan produk yang dipasarkannya.

Gugatan Product Liability dapat dilakukan berdasarkan tiga hal':

1. melanggar jaminan misalnya khasiat yang timbul tidak sesuai dengan janji yang tertera dalam kemasan produk.

2. ada unsur kelalaian yaitu podusen lalai memenuhi standar pembuatan obat yang baik.

3. menerapkan tanggung jawab mutlak

Berdasarkan kasus tentang peredaran obat kuat ilegal dengan merek Cobra'X jika dikaitkan dengan prinsip Product Liability adalah sesuai karena dilihat dari khasiat obat kuat yang diedarkan tidak memberikan jaminan kesehatan bahkan efek samping pada obat tersebut dapat menimbulkan kerugian bagi kesehatan, pelaku usaha

\footnotetext{
${ }^{6}$ Rita herlina, 2017, Tanggung Jawab Negara Terhadap Perlindungan Konsumen Ditinjau Dari Hukum Perdata, Perputakaan Nasional, Jakarta, h.35.

${ }^{7}$ Celina Tri Siwi Kristiyanti, 2011, Hukum Perlindungan Konsumen, Sinar Grafika, Jakarta, h. 97.
} 
juga tidak memenuhi standar pembuatan obat yang baik, seharusnya obat kuat dengan merek Cobra'X sudah tidak layak untuk edarkan karena tidak mendapatkan izin dari BPOM karena mengandung bahan kimia obat sehingga pada kasus tersebut sangat sesuai untuk diterapkan tanggung jawab mutlak.

Namun di dalam Undang-Undang Nomor 8 Tahun 1999 tentang Perlindungan Konsumen tidak memberikan rumusan yang jelas dan tegas terkait definisi dari jenis barang yang secara hukum dapat dipertanggungjawabkan dan sampai seberapa jauh suatu pertanggungjawaban atas barang tertentu dapat dikenakan bagi pelaku usaha tertentu atas hubungan hukumnya dengan konsumen. 8Tanggung jawab produk merupakan tanggung jawab produsen untuk produk yang dibawanya ke dalam peredaran yang menimbulkan kerugian karena cacat yang melekat pada produk tersebut.

Berkenaan dengan tanggung jawab produk, dapat dilihat di dalam Pasal 19 ayat (1) dan (2) Undang-Undang Nomor 8 Tahun 1999 tentang Perlindungan Konsumen. Pasal 19 ayat (1) menyebutkan bahwa pelaku usaha bertanggung jawab memberikan ganti rugi atas kerusakan, pencemaran, dan/atau kerugian konsumen akibat mengkonsumsi barang dan/atau jasa yang dihasilkan atau diperdagangkan. Selain itu, dalam Pasal 19 ayat (2) menyebutkan bahwa ganti rugi sebagaimana dimaksud pada ayat (1) dapat berupa pengembalian uang atau penggantian barang dan/atau jasa yang sejenis atau setara nilainya, atau perawatan kesehatan dan/atau

8I Made Dwija Di Putra, 2018, “Tanggung Jawab Penyedia Aplikasi Jual Beli Online Terhadap Konsumen Berdasarkan Undang-Undang Nomor 8 Tahun 1999 Tentang Perlindungan Konsumen", Kertha Semaya, h. 8. 
pemberian santunan yang sesuai dengan ketentuan peraturan perundang-undangan yang berlaku.

\section{Penutup}

\subsection{Kesimpulan}

Berdasarkan uraian yang telah dibahas diatas, maka dapat disimpulkan hal-hal yakni:

Perlindungan hukum terhadap konsumen terkait peredaran obat kuat ilegal dengan merek Cobra'X secara umum ditunjukkan melalui adanya Undang-Undang Nomor 8 Tahun 1999 tentang perlindungan konsumen pada Pasal 4, Pasal 7, Pasal 8 sampai dengan Pasal 17, Pasal 45 serta mendapatkan pengawasan dari lembaga-lembaga yang berwenang seperti BPOM. Sedangkan tanggung jawab pelaku usaha dalam hal konsumen mengalami kerugian akibat mengkonsumsi obat kuat ilegal adalah sesuai dengan Pasal 19 Undang-Undang Nomor 8 Tahun 1999 tentang Perlindungan Konsumen yang menyebutkan bahwa pelaku usaha bertanggung jawab memberikan ganti rugi berupa pengembalian uang atau penggantian barang dan/atau jasa yang sejenis atau setara nilainya, atau perawatan kesehatan dan/atau pemberian santunan yang sesuai dengan ketentuan peraturan perundang-undangan yang berlaku.

\subsection{Saran}

Berdasarkan kesimpulan yang telah diuraikan dengan permasalahan yang diangkat dan dibahas diatas, maka penulis memberikan masukan dan saran sebagai berikut :

1. Masyarakat selaku konsumen sebaiknya lebih aktif dalam melakukan pengaduan kepada BPOM apabila diketahui adanya 
obat kuat yang berdampak negatif dan dapat memberikan efek samping bagi penggunaannya.

2. Pemerintah Republik Indonesia sebaiknya perlu melakukan revisi atas Undang-Undang Nomor 8 Tahun 1999 Tentang Perlindungan Konsumen mengenai perlindungan kesehatan konsumen secara khusus dan definisi dari jenis barang yang secara hukum dapat dipertanggungjawabkan dan sampai seberapa jauh suatu pertanggungjawaban atas barang tertentu dapat dikenakan bagi pelaku usaha tertentu atas hubungan hukumnya dengan konsumen.

\section{DAFTAR PUSTAKA}

\section{A. Buku}

Herlina, Rita, 2017, Tanggung Jawab Negara Terhadap Perlindungan Konsumen Ditinjau Dari Hukum Perdata, Perputakaan Nasional, Jakarta.

Kristiyanti, Celina Tri Siwi, 2011, Hukum Perlindungan Konsumen, Sinar Grafika, Jakarta.

Nasution, Bahder Johan, 2008, Metode Penelitian Ilmu Hukum, Mandar Maju, Bandung.

Soekanto, M Soerjono, 2006, Pengantar Penelitian Hukum, UI-Press, Jakarta.

Zulham, 2018, Peran Negara Dalam Perlindungan Konsumen Muslim Terhadap Produk Obat Halal, Kencana, Jakarta.

\section{B. Jurnal Ilmiah}

Putra, I Made Dwija Di, 2018, Tanggung Jawab Penyedia Aplikasi Jual Beli Online Terhadap Konsumen Berdasarkan UndangUndang Nomor 8 Tahun 1999 Tentang Perlindungan Konsumen", Kertha Semaya.

\section{Internet}


Hikmah, Nurul, 2018, "Polisi Sita Ratusan Ribu Obat Kuat di Pintu Masuk Bali", Oke News, URL:

https://news.okezone.com/read/2018/04/11/340/1885311/p olisi-sita-ratusan-ribu-obat-kuat-di-pintu-masuk-bali diakses tanggal 4 April 2019

Humas dan DSP, 2018, "Siaran Pers BPOM RI Sita 15,7 Miliar

Rupiah Obat Tradisional Ilegal di Jakarta", Badan Pom, URL: https://www.pom.go.id/mobile/index.php/view/pers/429/SIA RAN-PERS--BPOM-RI-SITA-15-7-MILIAR-RUPIAH-OBATTRADISIONAL-ILEGAL-DI-JAKARTA.html diakses tanggal 17 Juni 2019

\section{Peraturan Perundang-Undangan}

Kitab Undang-Undang Hukum Perdata

Undang-Undang Nomor 8 Tahun 1999 tentang perlindungan konsumen

Peraturan Kepala Badan Pengawas Obat dan Makanan Nomor NOMOR HK.00.05.42.2996 Tentang Pengawasan Pemasukan Obat Tradisional 